\title{
Publisher Correction: A meiosis-specific BRCA2 binding protein recruits recombinases to DNA double-strand breaks to ensure homologous recombination
}

\author{
Jingjing Zhang ${ }^{1}$, Yasuhiro Fujiwara², Shohei Yamamoto ${ }^{3} \&$ Hiroki Shibuya ${ }^{1}$
}

Correction to: Nature Communications; https://doi.org/10.1038/s41467-019-08676-2; published online: 13 February 2019

The original version of this Article contained errors in Fig. 5. In panel g, the male and female symbols preceding each genotype were inadvertently converted to ' $\mathrm{B}$ ' and ' $\cong$ ', respectively. These errors have been corrected in both the PDF and HTML versions of the Article.

Published online: 25 February 2019

\begin{abstract}
(c) (i) Open Access This article is licensed under a Creative Commons Attribution 4.0 International License, which permits use, sharing, adaptation, distribution and reproduction in any medium or format, as long as you give appropriate credit to the original author(s) and the source, provide a link to the Creative Commons license, and indicate if changes were made. The images or other third party material in this article are included in the article's Creative Commons license, unless indicated otherwise in a credit line to the material. If material is not included in the article's Creative Commons license and your intended use is not permitted by statutory regulation or exceeds the permitted use, you will need to obtain permission directly from the copyright holder. To view a copy of this license, visit http://creativecommons.org/licenses/by/4.0/.
\end{abstract}

(C) The Author(s) 2019

\footnotetext{
${ }^{1}$ Department of Chemistry and Molecular Biology, University of Gothenburg, SE-40530 Gothenburg, Sweden. ${ }^{2}$ Institute for Quantitative Biosciences, University of Tokyo, 1-1-1 Yayoi, Tokyo 113-0032, Japan. ${ }^{3}$ Graduate Program in Bioscience, Graduate School of Science, University of Tokyo, Hongo, Tokyo 113-0033, Japan. These authors contributed equally: Jingjing Zhang, Yasuhiro Fujiwara. Correspondence and requests for materials should be addressed to H.S. (email: hiroki.shibuya@gu.se)
} 